\title{
Beware of the Third Eye: The Impact of Citizen Journalism in the Digital Age
}

\section{Thomas $\mathrm{CW}^{*}$}

Mass Communication Department, The Robertson School of Media and Culture, USA

\section{Introduction}

Citizen journalists are ordinary people who do not necessarily have journalistic training yet, they feel the duty and responsibility to participate in the journalistic process as need be. Just as professional journalists, they seek to facilitate a better society and world by presenting and speaking truth to power. They seek to answer the call of social responsibility. History is full of examples of citizen journalists dating back to the Gutenberg press and beyond. However, with the modern day coming of the digital age and the abundance of powerful, relatively inexpensive technology and applications (digital cameras, smart phones, laptop computers, the internet, blogging, and digital sharing in numerous forms) the job of the citizen journalist has become much easier and more powerful.

With such technology, citizen journalists have, in essence, become a Third Eye of observation in today's world (The First Eye being power-Mega Business/Government and the Second Eye being the subjects/ objects/victims of said power). The Third Eye consists of third party bystanders who happen to be equipped with the needed technology and who have the duty, responsibility, and urge to use it. There are numerous cases in point. Not the least of these cases is Rodney King, Walter Scott, and most recently, Freddie Gray.

In one of the most famous milestone cases of third party video documentation, a Los Angeles taxi cab driver, Rodney Kings, was captured on video being beaten by four police officers. The video of this 1991 incident resulted in the four officers being charged with assault via deadly weapon and use of excessive force. After three of the officers were acquitted of all charges, the city of Los Angeles was faced with riots which resulted in 53 deaths and over 2000 people injured.

Although many similar cases have happened since the King case, another milestone case occurred in April 2015. At that time, a police officer in South Carolina was charged with murder in the death of Walter Scott. Scott was shot in the back numerous times by the officer following a routine traffic stop. The shooting was captured on video by a third party bystander. The video was instrumental in facilitating the murder charges.

Most recently, it was alleged that Freddie Gray, of Baltimore, was injured during an arrest. He later died after suffering from a broken vertebra. Two witnesses recorded Gray's arrest. The arrest and death are now under investigation. Beware, the Third Eye is watching!
*Corresponding author: Thomas CW, Mass Communication Department The Robertson School of Media and Culture, USA, Tel: 804-827-3772; E-mail: cwthomas@vcu.edu

Received April 21, 2015; Accepted April 24, 2015; Published April 30, 2015

Citation: Thomas CW (2015) Beware of the Third Eye: The Impact of Citizen Journalism in the Digital Age. J Mass Communicat Journalism 5: e159. doi:10.4172/2165-7912.1000e159

Copyright: $\odot 2015$ Thomas CW. This is an open-access article distributed under the terms of the Creative Commons Attribution License, which permits unrestricted use, distribution, and reproduction in any medium, provided the original author and source are credited. 